\title{
Stingless bee floral visitation in the global tropics and subtropics
}

Francisco Garcia Bulle Bueno ${ }^{1}$, Liam Kendall ${ }^{2}$, Denise Araujo Alves ${ }^{3}$, Manuel Lequerica Tamara ${ }^{4}$, Tim Heard, ${ }^{1}$ Tanya Latty ${ }^{5}$, Rosalyn Gloag ${ }^{1}$

1 Behaviour, Ecology and Evolution Laboratory, School of Life and Environmental Sciences A12, University of Sydney, Sydney NSW 2006, Australia. ${ }^{2}$ Centre for Environmental and Climate Science, Lund University, Sölvegatan 37, S-223 62 Lund, Sweden

3 Department of Entomology and Acarology, Luiz de Queiroz College of Agriculture, University of São Paulo, Avenida Pádua Dias 11, Piracicaba, Brazil.

${ }^{4}$ Integrative Ecology Lab, School of Life and Environmental Sciences A08, University of Sydney, Sydney NSW 2006, Australia.

${ }^{5}$ Invertebrate Behaviour and Ecology Lab, School of Life and Environmental Sciences A08, University of Sydney, Sydney NSW 2006, Australia.

\begin{abstract}
Bees play a key role in maintaining healthy terrestrial ecosystems by pollinating plants. Stingless bees (Apidae: Meliponini) are a diverse clade of social bees ( $>500$ species) with a pantropical distribution spanning South and Central America, Africa, India and Austral-Asia. They are garnering increasing attention as commercially-beneficial pollinators of some crops, yet their contribution to the pollination of native plants in the tropics and subtropics remains poorly understood. Here we conduct for the first time a global review of the plants visited by stingless bees. We compile a database of reported associations (flower visits) between stingless bees and plants, from studies that have made either direct observations of foraging bees or analysed the pollen stored in nests. Worldwide, we find stingless bees have been reported to visit the flowers of plants from at least 215 different families and 1434 genera, with frequently reported interactions for many of the tropic's most species-diverse plant families including Fabaceae, Asteraceae, Rubiaceae, Poaceae, Euphorbiaceae, Myrtaceae, Malvaceae, Arecaceae, Solanaceae, and Anacardiaceae. The stingless bee fauna of each of three major biogeographic regions (Neotropical, Afrotropical and Indo-Malayan-Australasian) were frequent visitors of
\end{abstract}


many of the same plant families, however we detected differences in the proportional use of plant families by the stingless bees of the Indo-Malayan-Australasian and Neotropical regions, likely reflecting differences in the available flora of those regions. Stingless bees in all regions visit a range of exotic species in their preferred plant families (crops, ornamental plants and weeds), in addition to native plants. Although most reports of floral visitation on wild plants do not confirm effective pollen transfer, it is likely that stingless bees make at least some contribution to pollination for the majority of plants they visit. In all, our database supports the view that stingless bees play an important role in the ecosystems of the global tropics and subtropics as pollinators of an exceptionally large and diverse number of plants. This database also highlights important gaps in our knowledge of stingless bee resource use and should benefit future efforts to understand stingless bee-plant interactions.

\section{Introduction}

Animal pollination is critical to ecosystem functioning and service provisioning in terrestrial ecosystems globally (Klein et al., 2006, Fontaine et al., 2005, Potts et al., 2016b). A diverse range of vertebrates and arthropods may pollinate plants, but the majority of plant species (65$80 \%$ ) rely on insects as their primary pollinators (Buchmann and Nabhan, 2012, Ollerton et al., 2011). There is growing evidence of widespread declines in insect pollinator populations over recent decades, in some cases causing synergistic declines in pollinator-dependent plants (Biesmeijer et al., 2006, Potts et al., 2016b). The plants of the species-rich tropics and subtropics may be particularly vulnerable to changes in insect populations, as the flora of these regions are more dependent on pollinators than those of temperate-zones ( $94 \%$ of all tropical plants are estimated to rely on animal-pollination (Ollerton et al., 2011). In addition, insects in the tropics are predicted to be the least capable of rapidly adapting to changing climates, and thus the most at risk of extinction (Kellermann et al., 2012). In order to mitigate the impacts of pollinator declines in the tropics and subtropics, we first require a greater understanding of pollinator ecology in these regions (Vanbergen and Initiative, 2013), and the relationship between floral resources and pollinators at landscape scales (Vanbergen and Initiative, 2013, Kleijn and Raemakers, 2008).

The stingless bees (Hymenoptera: Apoidea: Anthophila: Meliponini) are social corbiculate bees native to the world's tropical and subtropical regions (Michener, 2000, Michener, 1979, 
Roubik, 1992a). Like other social bees (e.g. honey bees, Apis sp.), stingless bees are abundant flower visitors in the ecosystems they inhabit, because each colony contains thousands to tens of thousands of workers (Nogueira Neto, 1997, Hepburn and Radloff, 2011). There are an estimated 516 species of stingless bees in 60 genera (Schuh, 2010, Rasmussen and Cameron, 2007, Rasmussen and Cameron, 2010). These are divided between three monophyletic clades that diverged from each other 50-70 million years ago and that correspond to three major biogeographic regions: Neotropical, African and Indo-Malayan-Australasian (Rasmussen and Cameron, 2010). The Neotropics harbours the greatest stingless bee diversity, with 417 known species, c. $80 \%$ of all stingless bee species(J. S. Moure \& A. Dal Molin, 2012).

The high global species diversity of stingless bees is also reflected in their morphological and behavioural diversity (Michener, 2000). They range in body size from just $2 \mathrm{~mm}$ (some Trigonisca spp.; Roubik, 2018) to $15 \mathrm{~mm}$ (Melipona fuliginosa; Camargo and Pedro, 2008). They may nest in tree cavities, termite nests, or underground (Roubik, 1983). In the absence of an effective sting, they have evolved varied defence mechanisms including acid discharge (Roubik et al., 1987), suicidal biting (Shackleton et al., 2015) and sticking resin (Lehmberg et al., 2008). And they show a variety of social structures, whereby colonies may have multiple queens or single queens (Velthuis et al., 2006, Alves et al., 2011), workers may lay eggs regularly or be completely sterile (Sommeijer et al., 1999, Garcia Bulle Bueno et al., 2020), and the workers of some species include a "solider caste" (Baudier et al., 2019, Hammel et al., 2016, Grüter et al., 2012). All stingless bees, however, share a need to visit flowers for nectar for food, and almost all also collect pollen to provision their offspring (excluding a handful of Neotropical species that feed their offspring carrion or are cleptoparasites of other stingless bees; Sakagami et al., 1993, Mateus and Noll, 2004). Stingless bees therefore contribute to pollinating the native flora of forests throughout the world's tropics and subtropics (Gill et al., 2016).

Stingless bees have attracted significant research as pollinators of crops in many of the countries where they naturally occur (Giannini et al., 2015, Ish-Am et al., 1999, Nates Parra, 2016). Similar to honeybees, stingless bees can be readily kept and transported in hives (Wille, 1983, Nogueira Neto, 1997) meaning they can be introduced to orchards when in flower and then reallocated (Giannini et al., 2020). They are effective pollinators of a variety of tropical and subtropical crops species, including açaí palm (Euterpe oleracea) coconut (Cocos nucifera), coffee (Coffea arabica), macadamia (Macadamia spp.) and rambutan (Nephelium 
lappaceum) (Giannini et al., 2015, Heard, 1999, Slaa et al., 2006). They are also adapted to the local conditions in many regions where these crops are grown (Jaffé et al., 2015), with wild stingless bees providing valuable free pollination services. For example, wild stingless bees in Eastern Australia (Tetragonula sp.) are as effective as managed honey bees at pollinating exotic blueberry crops (Vaccinium spp.) (Kendall et al., 2020). In most parts of the world, however, our understanding of the relationship between stingless bees and native flora is comparatively incomplete (Roubik, 1995, Giannini et al., 2020). Stingless bees actively forage on diverse floral resources throughout the year (Roubik, 1982, Roubik, 1992b, Kleinert et al., 2012), but are proposed to have stronger interactions with some groups of native plants than others (e.g. Asteraceae, Euphorbiaceae, Sapindaceae, Rubiaceae, Fabaceae, Melastomataceae and Myrtaceae; Grüter, 2020). Such preferences might confer a benefit on stingless bees via a reduction in interspecific competition (i.e. they focus on resources neglected by Apis sp.), or they may simply select those flowers that produce nectar and pollen in most abundance (Antonini et al., 2006, Ramalho et al., 1989). At least some genera (e.g. Melipona spp. in the Neotropics) show a clear preference for some floral resources over others, irrespective of availability (Vossler, 2013, Ramalho et al., 1991, Ramalho et al., 1990, Kleinert et al., 2012, Antonini et al., 2006).

Here, we aim to consolidate current knowledge of stingless bee floral visitation of native plants at the regional and global scale, by creating a database of reported floral visitation by stingless bees. From this database, we assess: (i) the diversity of plant families and genera used as food sources by stingless bees in each of three major biogeographical regions: Neotropical, Afrotropical and Indo-Malayan-Australasian; (ii) the most frequently-used plant families (according to number of genera visited), as a proxy for candidate floral preferences of stingless bees; and (iii) the type of growth, endemism to a particular region, and native or exotic status of plants commonly used as forage by stingless bees. We also provide a reference list of those plants for which stingless bees have been experimentally confirmed to be pollinators (both crops and wild plants). Our database is intended as a first step towards a richer understanding of how stingless bees contribute to ecosystem functioning in the tropics and subtropics, and provides an online resource for further studies on plant-pollinator interactions. 


\section{Methods}

\section{Database of floral visitation by stingless bees}

To build a database of reported interactions between stingless bees and flowering plants, we conducted a search of peer review journals, books, student theses and conference abstracts. We used the keywords Meliponini, pollination, floral preferences and stingless bees to search Scopus, Web of Science and Google Scholar (first 200 references per search; May 2020). We likewise searched unpublished literature in Spanish and Portuguese from library databases and the University repositories of The National University of Colombia, The University of Costa Rica and The University of Brazil (Catálogo de Teses e Dissertações Literature Teses CAPES, from 2013 to now; CAPES, 2016), plus the Conference abstracts from the annual Brazilian Bee Meeting "Encontro sobre Abelhas" (1994 to 2018). Finally, we included reported interactions from Brazil's online index of Bee-Plant Interactions (A.B.E.L.H.A., 2017), and from three books: 'Pot Pollen' (Vit et al., 2018), 'Atlas of Pollen and Plants used by Bees' (da Silva et al., 2020) and 'Pollination of cultivated plants in the tropics' (Roubik, 1995). We only included literature that was available online.

From each source, we collated the following information for each stingless bee species-flower interaction: biogeographic region (Neotropical, Afrotropical, Indo-Malayan-Australasian) and country where the interaction was reported, plant species, genus and family, bee species and type of interaction (either floral visitation or pollination). Floral visitation included cases where the researcher directly observed bees visiting flowers, or where visitation was inferred from palynological study (i.e. pollen resources collected from colonies or off the legs of returning foragers). An interaction was scored as pollination only if the study confirmed the bee pollinated the plant. We did not consider pollination efficiency (i.e. single visit efficiency of pollen deposition, fruit set, seed set, etc.; (King et al., 2013) as only a handful of studies in our database reported such detail. Finally, for the 15 plant families with the greatest number of genera visited by stingless bees, we retrieved the native distribution of each genera and the growth type using Plants of the World Online (POWO, 2019) and noted whether the genus was documented as introduced in the region of the reported interaction according to the Centre for Agriculture and Bioscience International (CABI, 2020). 
We considered commonly used plant families to be those in which stingless bees were reported to visit the most genera within the family. For the Neotropical region, we also accessed data on the total number of genera per plant family known to occur in the region via Neotropikey (Milliken, 2009), an online key developed to identify and inform about the flowering plants in the Neotropical region. This allowed us to account for high richness of genera in some plant families, by considering the proportion of locally-occurring genera in a family that were visited by stingless bees.

To confirm our database used current scientific names of all stingless bees, we checked names against the "Catalogue of Bees (Hymenoptera, Apoidea) in the Neotropics" (J. S. Moure \& A. Dal Molin, 2012), the "Catalogue of Afrotropical bees (Hymenoptera: Apoidea: Apiformes)" (Eardley and Urban, 2010) and the "Catalogue of the Indo-Malayan/Australasian stingless bees (Hymenoptera: Apidae: Meliponini)" (Rasmussen, 2008). For plant species, we cross-checked names against those listed on the Missouri Botanical Garden's Tropicos website (Missouri Botanical Garden, 2020), The Plant List (The Plant List, 2010), Plants of the World Online (POWO, 2019) and the R package taxize v0.9.98 (Chamberlain and Szöcs, 2013).

\section{Analyses}

We visualised plant $\sim$ pollinator networks for the top ten most abundant bee genera and plant families using chord diagrams (circlize package v0.4.1; Gu et al., 2014). We also provide example flower types for each plant family in chord diagrams, based on (Simpson, 2010).

We tested whether the plant families visited by stingless bees varied between biogeographical regions (Neotropical, Afrotropical and Indo-Malayan-Australasian) using a two-step approach. First, we transformed our databases to interaction matrices of bee genera (rows) $\sim$ plant family (columns, count of the number of visited genera) and then calculated the Bray-Curtis dissimilarity between bee genera using the vegan package v2.5-6 (Oksanen et al., 2013). Second, we compared compositional differences in plant use (at family level) between biogeographical regions using a pairwise PERMANOVA (Anderson, 2001, Martinez Arbizu, 2017). We adjusted $P$-values using the false discovery rate (FDR) method to account for multiple comparisons (Benjamini and Hochberg, 1995). We visualised differences in the interactions between stingless bees and plant families in two-dimensional space with non- 
metric multidimensional scaling (nMDS) ordination. We conducted all data analyses in $\mathrm{R}$ v4.0.2 (R Core Team, 2013).

\section{Results}

Our database includes 19,770 bee-flower interactions reported in 541 studies (Table S1). In all, 287 species of stingless bees were represented by at least one reported interaction in the database; this spanned 52\% (219/417) of Neotropical stingless bee species, $68 \%(22 / 32)$ of Afrotropical species and 51\% (46/89) of Indo-Malayan-Australasian species. The great majority of reported interactions were floral visitation records (19,006 interactions, 96\%), with the remainder (764 interactions, 4\%) confirming that bee visitation resulted in pollination. 
bioRxiv preprint doi: https://doi.org/10.1101/2021.04.26.440550; this version posted April 27, 2021. The copyright holder for this preprint (which was not certified by peer review) is the author/funder, who has granted bioRxiv a license to display the preprint in perpetuity. It is made available under aCC-BY-ND 4.0 International license.

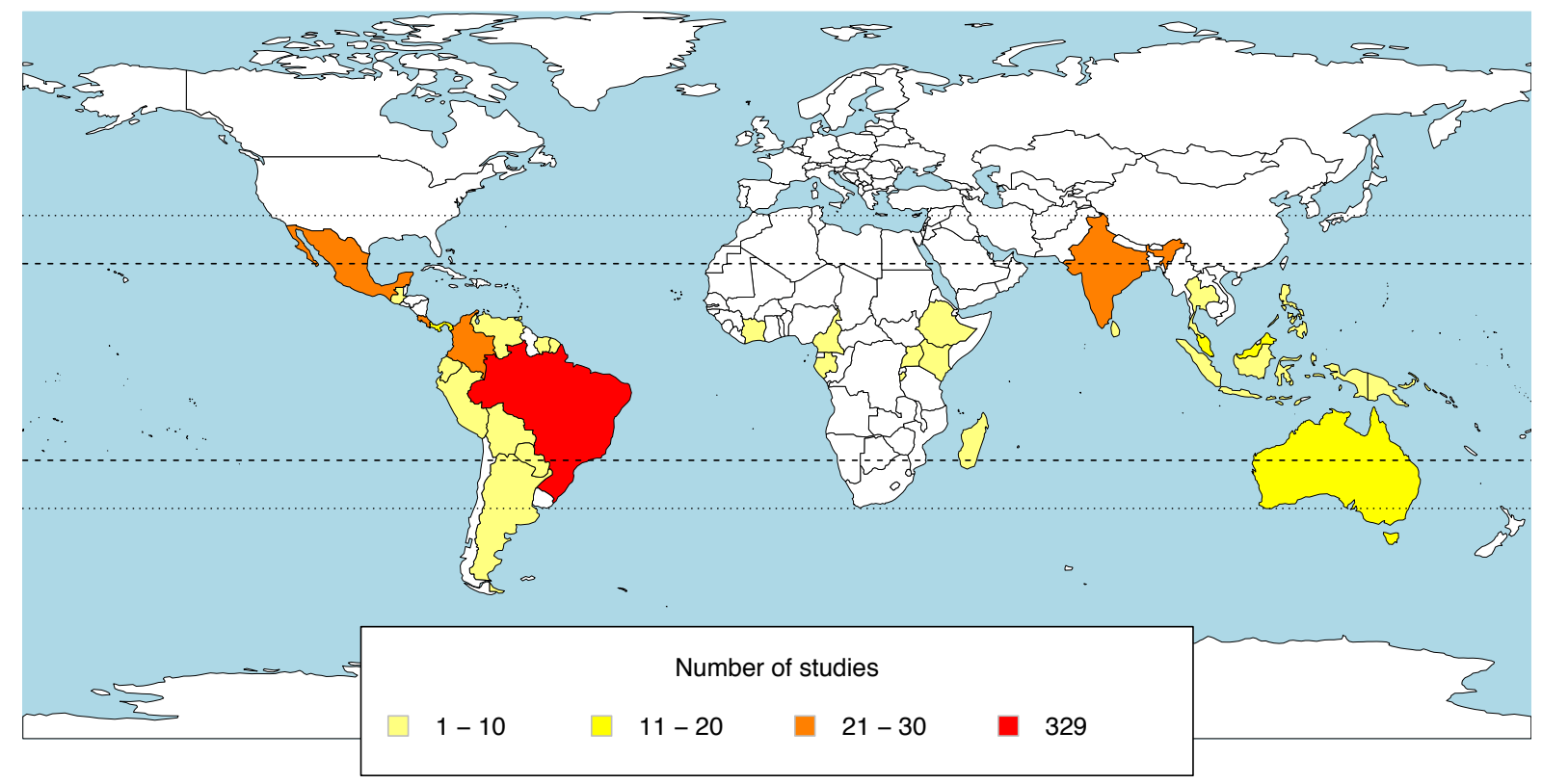

Figure 1. To visualise bias in reported stingless bee-plant interactions in the available literature, we plotted the number of studies that recorded interactions between stingless bees and flowering plants at a country level per region included in our database using rworldmap (v.1.3-6, South 2011). Dashed and dotted lines indicate the latitudinal range of the Tropics and Subtropics respectively. 


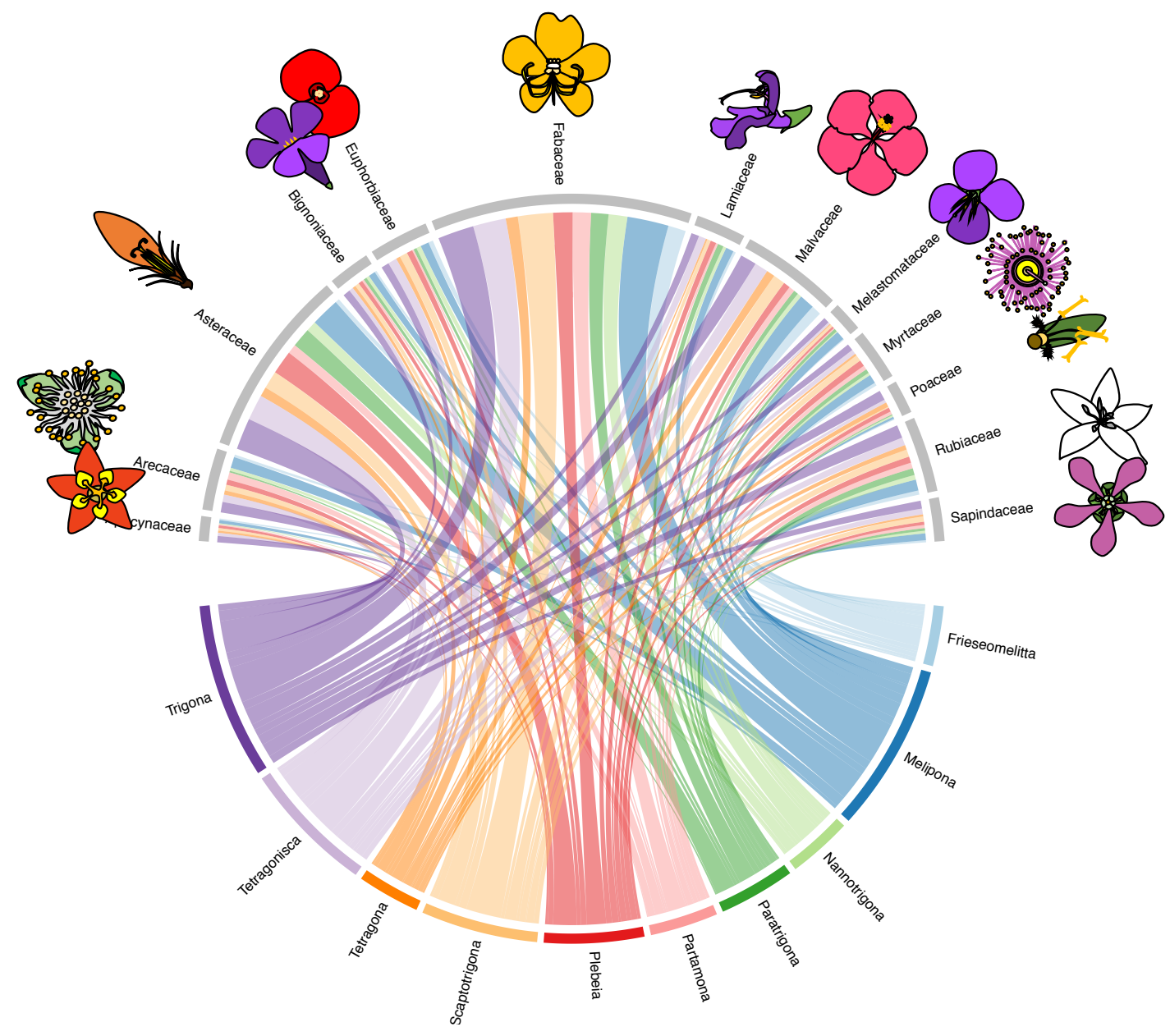

Figure 2A. A visitation network of stingless bees to flowering plants in the Neotropical region, showing the 10 stingless bee genera and 10 plant families with the most reported interactions in the literature. Example flower types for each plant family are shown. Details of all interactions are given in supplementary material, Table S1. 
bioRxiv preprint doi: https://doi.org/10.1101/2021.04.26.440550; this version posted April 27, 2021. The copyright holder for this preprint (which was not certified by peer review) is the author/funder, who has granted bioRxiv a license to display the preprint in perpetuity. It is made available under aCC-BY-ND 4.0 International license.

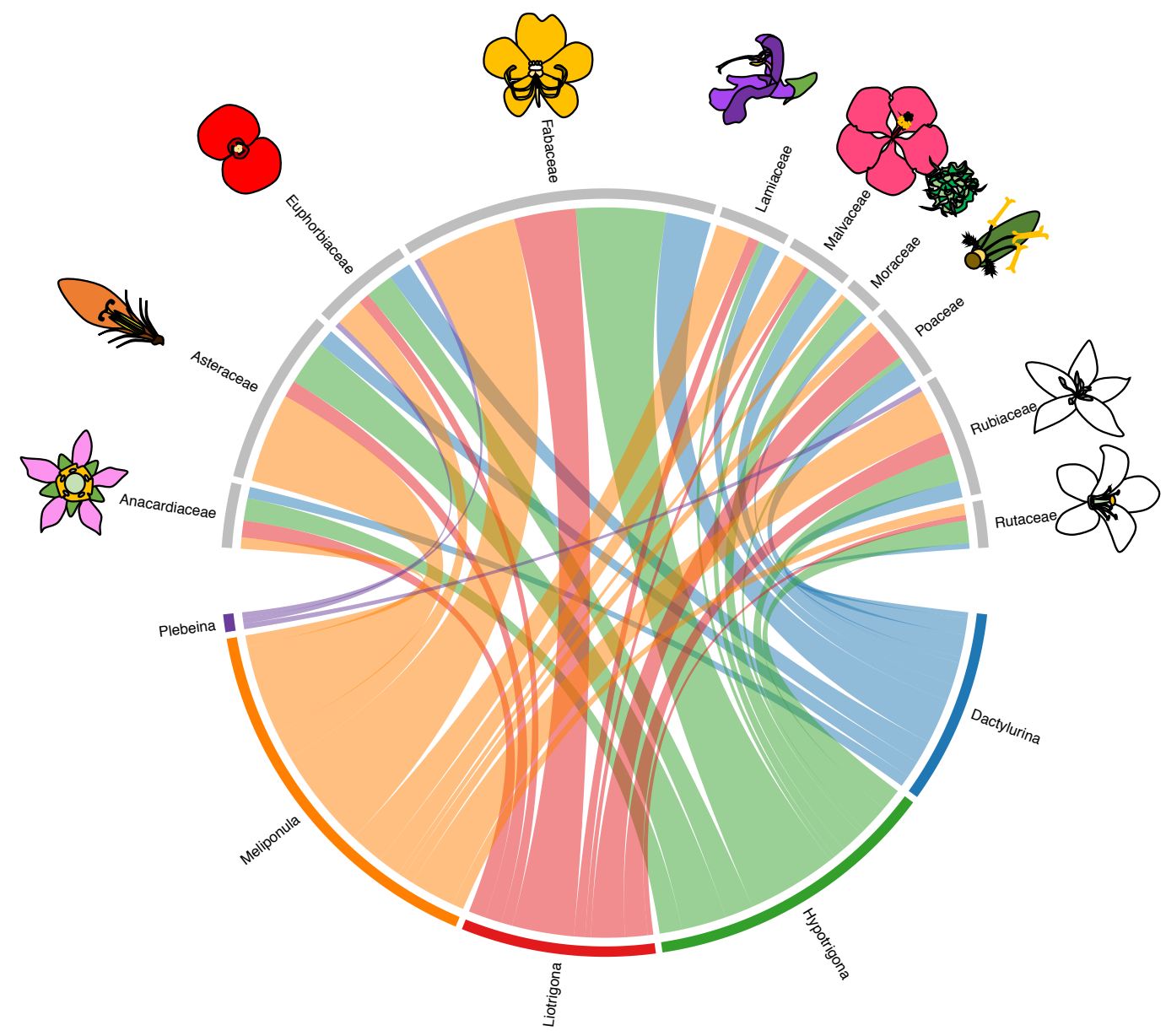

Figure 2B. A visitation network of stingless bees to flowering plants in the Afrotropical region, showing the 5 stingless bee genera and 10 plant families with the most reported interactions in the literature. Example flower types for each plant family are shown. Details of all interactions are given in supplementary material, Table S1. 


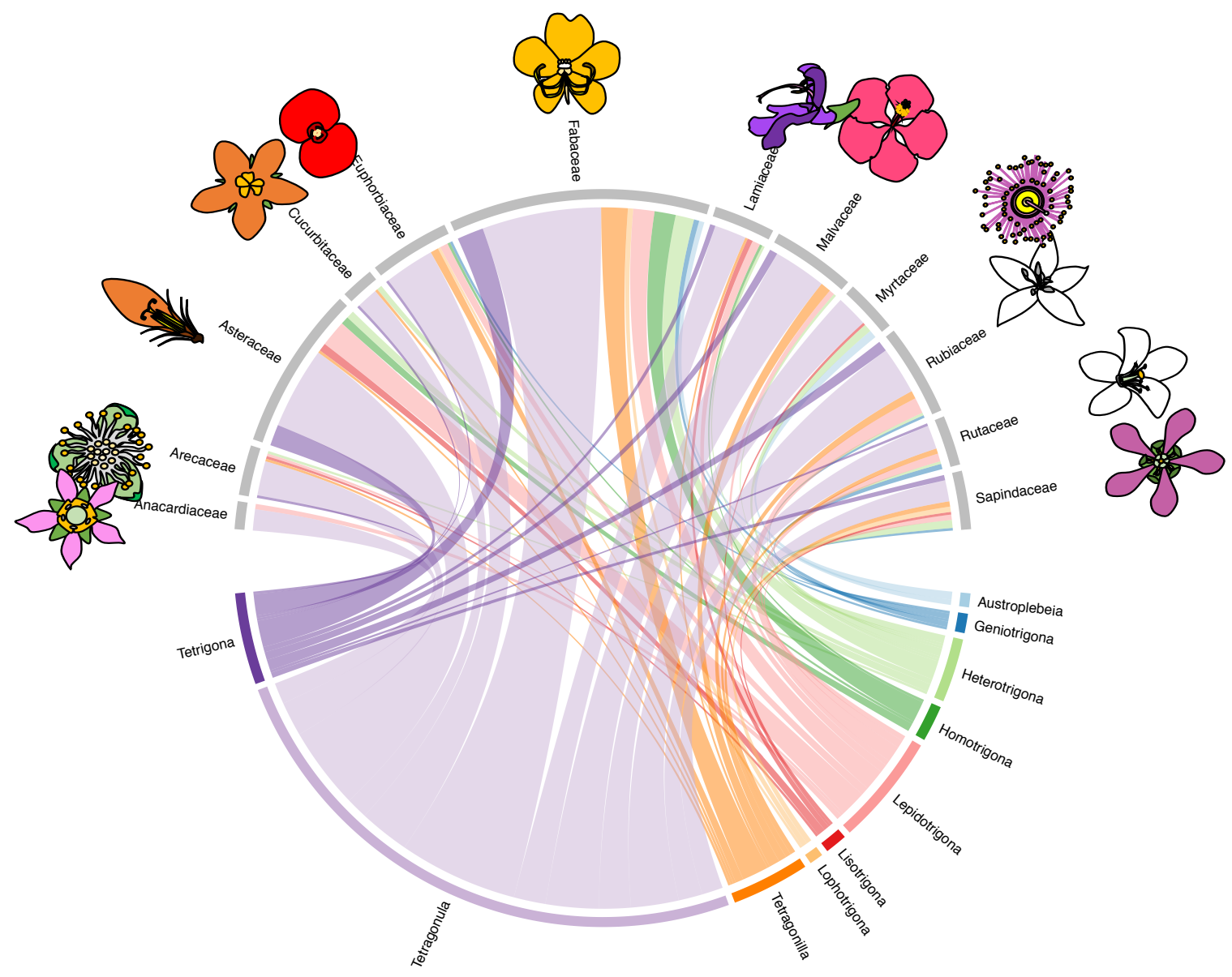

Figure 2C. A visitation network of stingless bees to flowering plants in the Indo-Malayan-Australasian region, showing the 10 stingless bee genera and 10 plant families with the most reported interactions in the literature. Example flower types for each plant family are shown. Details of all interactions are given in supplementary material, Table S1. 
bioRxiv preprint doi: https://doi.org/10.1101/2021.04.26.440550; this version posted April 27, 2021. The copyright holder for this preprint (which was not certified by peer review) is the author/funder, who has granted bioRxiv a license to display the preprint in perpetuity. It is made available under aCC-BY-ND 4.0 International license.
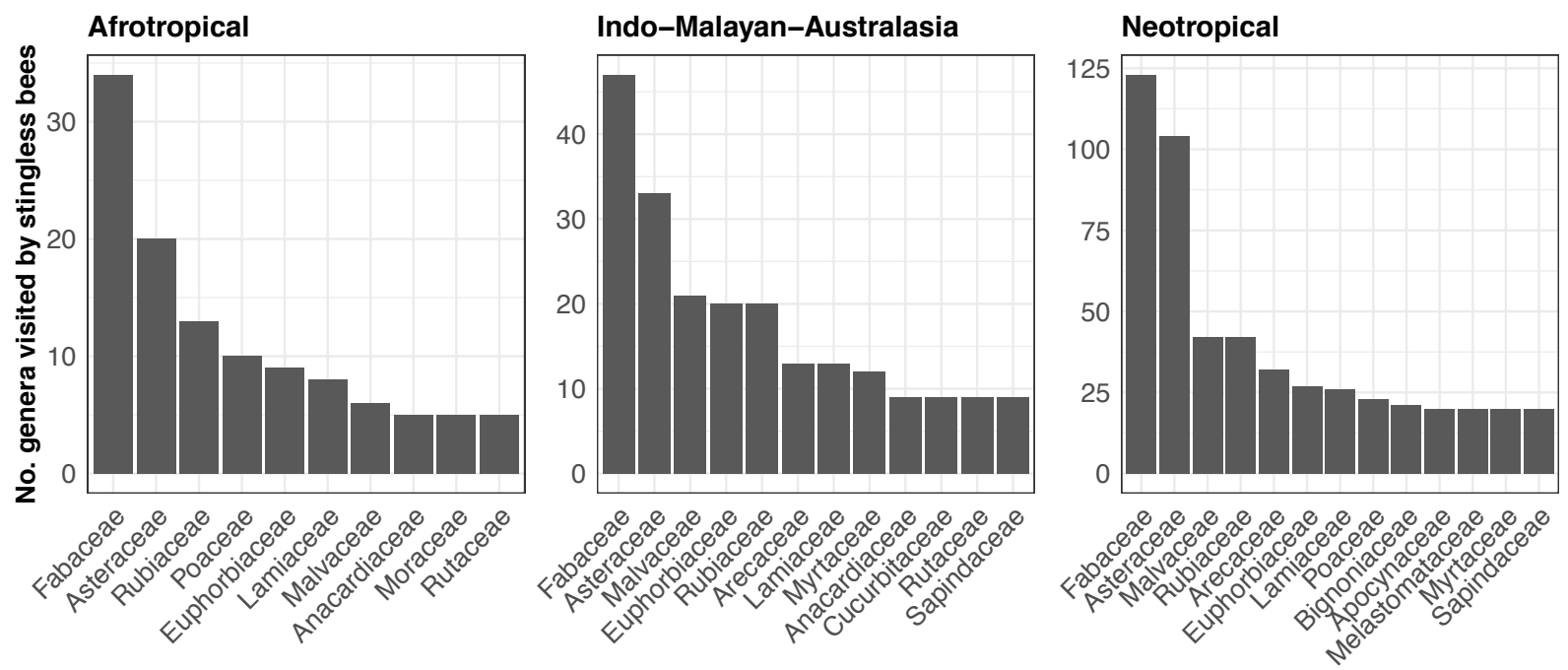

Figure 3. The number of genera visited by stingless bees of the Neotropical, Afrotropical and IndoMalayan-Australasian regions, in each of the 10 plant families with the highest number of genera visited, according to reported interactions in the literature ( $>10$ families shown where multiple families had the same rank). 


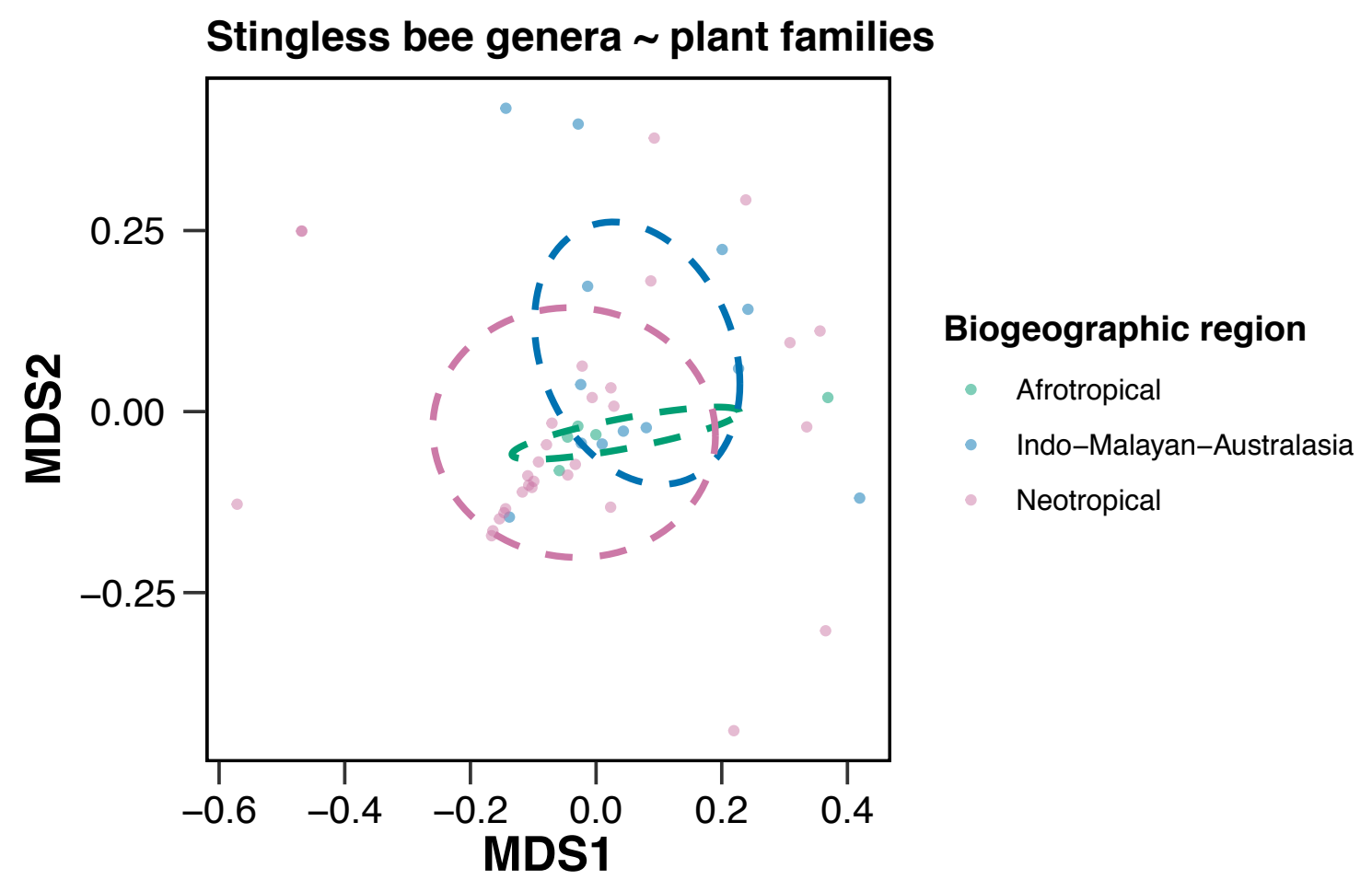

Figure 4. NMDS ordination of stingless bee genera $\sim$ plant family composition in each biogeographic region. Each point represents a bee genera's floral associations at the plant family level (Afrotropical, $\mathrm{N}=5$ bee genera; Indo-Malayan-Australasian, $\mathrm{N}=13$; Neotropical, $\mathrm{N}=31$ ). Dashed circles represent the 95\% confidence ellipses for each biogeographic region mean (group centroid). 


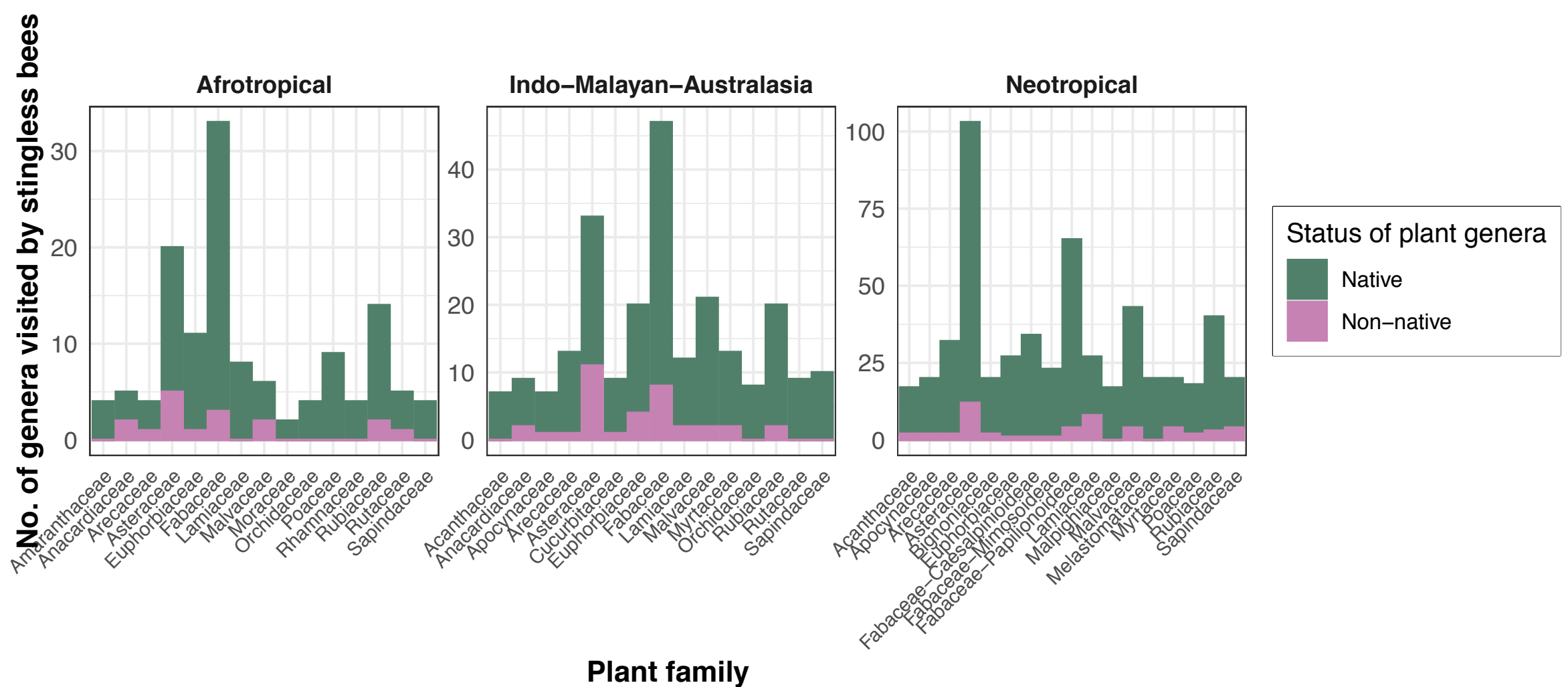

Figure 5. The number of genera visited by stingless bees in the 10 most visited plant families coded by native status, for each of three biogeographical regions: Afrotropical, Indo-Malayan-Australasian and Neotropical (>10 families shown where multiple families had the same rank). Most reported flower visits are for plant genera native to that region (green) but a minority are plant genera introduced to that region (pink). For the Neotropics, Fabaceae is shown here divided into its subfamilies (Caesalpinioideae, Mimosoideae and Papilionoideae) due to the large number of visited genera in that region. 
The majority of reviewed studies were carried out in the Neotropics (16900 interactions reported in 424 studies; 85\% of all interactions), and particularly Brazil (13619 interactions); Figure 1. This reflects in part the higher diversity of stingless bees in this region (e.g. half of the world's stingless bee genera are found in Brazil), and in part the intensity of research to date on the Neotropical stingless bee fauna, relative to that of the Afrotropics (1068 interactions reported in 17 studies; 5\% of database interactions), and Indo-Malayan-Australasia (1803 interactions reported in 57 studies; 10\% database interactions); Figure 1. Although our database included some "grey literature" (conference abstracts, student theses, etc) from the Neotropics but not from other regions, the proportion of total interactions reported from the Neotropics was similarly high even if we included only bee visitations that were published in international journals.

\section{Plant genera and families visited by stingless bees}

Stingless bees worldwide are reported to forage from the flowers of 1435 genera of plants in 215 families worldwide (205 families in the Neotropics, 82 in the Afrotropics and 137 in the Indo-Malayan-Australasian region); (Supplementary Material, Tables S2 and S3 ). Individual stingless bee species were reported to forage on $30 \pm 56$ (SD) plant genera (with the maximum reported as 535 plant genera for the neotropical species Trigona spinipes).

The ten plant families with the largest number of genera visited by stingless bees were Fabaceae (legumes; $\mathrm{N}=153$ ), Asteraceae (daisies; $\mathrm{N}=121$ ), Rubiaceae (madders; $\mathrm{N}=63$ ), Malvaceae (mallows; N=52), Euphorbiaceae (spurges; N=42), Arecaceae (palms; N=41), Lamiaceae (mints; N=34), Poaceae (grasses; N=33), Myrtaceae (myrtles; $\mathrm{N}=26$ ), Apocynaceae (dogbanes), Bignoniaceae (bignonias), Melastomataceae (melastomes), Orchidaceae (orchids) and Sapindaceae (soapberries) (equal $10^{\text {th }}, \mathrm{N}=25$ each); Figures 2A-C, Figure 3, Supplementary Material, Figure S1). All these families are highly diverse in number of genera and species, and all have pantropical distributions (Bramley and Utteridge, 2014).

In the Neotropics, the plant families for which the greatest proportion of total genera occurring in the region are visited by stingless bees were Myrtaceae (stingless bees are reported to visit $55 \%$ of all genera described for the Neotropics), Arecaceae (44\%) and Bignoniaceae (43\%) (Supplementary Material, Table S4). 
Several plant families are reported to be commonly used by the stingless bees of all geographic regions (e.g. Fabaceae, Asteraceae, Euphorbiaceae); Figure 3. Nevertheless, there were differences in the composition of reported plants (at family level) visited by the stingless bees of each biogeographical region (PERMANOVA: $P=0.01, \mathrm{R}^{2}=0.07$, Figure 4, Supplementary Material, Table S5). This trend was driven particularly by differences in the floral use of Neotropical and Indo-Malayan-Australasian stingless bee fauna, presumably reflecting differences in the plant communities available to bees in these two regions $(P=0.015$, $\mathrm{R} 2=0.053$ ). Afrotropical stingless bee floral use (at plant family level) did not differ significantly from either other region (Indo-Malayan-Australasian: $P=0.064, \mathrm{R} 2=0.091$; Neotropical: $P=0.072, \mathrm{R} 2=0.043)$.

\section{Traits of highly visited plant genera}

Across all visited plants, stingless bees visited genera of plants spanning a variety of common types of growth (herbs, trees, shrubs, vines, lianas) and including economically important plants such as crops, timber, fibres, medicinal and ornamental use (Supplementary Material, Table S3).

In addition to native flora, stingless bees were reported to visit non-native plants (Figure 5). We identified 109 genera of plants that are not native to the region where the bee-plant interaction was reported (52 in the Neotropics, 17 in the Afrotropics and 39 in the IndoMalayan-Australasian region; Supplementary Material, Table S6). Of these 19 (18\%) were common edible crops, such as rambutan (Nephelium sp.), lychee (Litchi sp.) and coffee (Coffea sp.) in the Neotropics, mango (Mangifera sp.), hog-plum (Spondias sp.) and corn (Zea sp.) in the Afrotropics, and oil-Palm (Elaeis sp.), tamarind (Tamarindus sp.) and guava (Psidium sp) in the Indo-Malayan-Australasian region. The remaining genera were non-native garden and ornamental plants, or have been documented as weeds (CABI, 2020); these included numerous genera of Lamiaceae (mint, sage etc.) and Asteraceae (daysies, dandelions, whiteweed, etc).

\section{Discussion}

We consolidated records of floral visitation of wild plants by stingless bees around the world. These records highlight the wide variety of plants used as forage by individual stingless bee 
species (as many 535 plant genera for Trigona spinipes), and by the Meliponini in general. Worldwide, stingless bees visit over 1435 genera from 250 families of flowering plants, around $62 \%$ of all angiosperm families (The Plant List, 2010). This summary of floral use therefore supports the view that stingless bees play an important role in ecosystem functioning throughout their native range, as pollinators of many tropical and subtropical plants.

\section{Plants used by stingless bees}

Globally, stingless bees forage from the flowers of 25 or more genera from each of 13 major tropical plant families: Fabaceae, Asteraceae, Rubiaceae, Malvaceae, Euphorbiaceae, Arecaceae, Lamiaceae, Poaceae, Bignoniaceae, Myrtaceae, Sapindaceae, Apocynaceae and Melastomataceae. The frequent use of several of these plant families has been previously reported at local scales for various stingless bee species of the Neotropics, which commonly use Fabaceae, Asteraceae, Myrtaceae, Malvaceae and Arecaceae (Antonini et al., 2006, Ramalho, 1990, Miranda et al., 2015, Ramalho et al., 1989, Cortopassi-Laurino and Ramalho, 1988, Faria et al., 2012, Aleixo et al., 2013, Ramalho et al., 1985, Guibu et al., 1988). We find that most of the plant families reported to be commonly visited by stingless bees are found in every tropical region (Americas, Africa, India, Austral-Asia), suggesting that broad foraging preferences are shared across each of the three major stingless bee clades. However, based on available reported floral visitations, the relative use of different plant families differs between the stingless bees from the Indo-Malayan-Australasian and Neotropical regions. This likely indicates, at least in part, differences in the abundance and availability of each plant family in the different regions. For example, bignonias (Bignoniaceae) appear more frequently in visitation records of Neotropical stingless bees than those of other regions, and the greatest diversity of bignonias is also in the Neotropics (Gentry, 1980, Gentry, 1992). It remains to be investigated whether some differences in floral use between regions also reflect different foraging preferences of the stingless bees in each clade, or different coevolutionary histories between the bees and flora of each region.

Floral morphology regulates the accessibility to floral resources for animal visitors. Many of the plant families commonly visited by stingless bees have floral traits that have evolved to favour animal visitation, and bee visitation in particular. For instance, the flowers of Myrtaceae, Arecaceae, Asteraceae, Malvaceae and Fabaceae (Subfamily: Mimosoideae) have open corollas with many stamens and longitudinally opened anthers, which facilitates the 
acquisition of pollen and nectar by bees (Lewis, 2005, Torres and Galetto, 2002). All of the plant genera visited by stingless bees are themselves "generalists" with respect to pollinators and all attract other pollinating insects or vertebrates. Notably, stingless bees do not visit some flower types, such as those with long and narrow corollas (e.g. some species from Lamiaceae) that have instead specialized on one or several species of long-tongued visitors (e.g. Euglossini (orchid bees) (Rodríguez-Gironés and Santamaría, 2006, Borrell, 2005). This morphological match between the traits of flowers and the mouthparts of insects plays a major role in floral resource partitioning (Nagamitsu and Inoue, 2005). Even within a single bee clade such as stingless bees (short tongued bees), some variation in tongue length and tongue shapes may affect their floral preferences (Nagamitsu and Inoue, 2005) and help to avoid competition with sympatric short-tongued bees (Inouye, 1978).

For all three biogeographical regions, Fabaceae and Asteraceae had the most genera visited by stingless bees. These families are also the two most speciose angiosperm families in the world (Christenhusz and Byng, 2016). Asteraceae and Fabaceae tend to dominate as bee-forage plants in tropical areas with open vegetation, including where forests have been cleared for human activities (Ramalho et al., 1990). For example, plants in these families may be the first ones to appear after forest disturbance and clearance (Valdez-Hernández et al., 2014, Citadini-Zanette et al., 2017). The ready use of these plants by stingless bees may thus help to explain their resilience in disturbed habitats, when other sources of forage are not available (Aizen et al., 2012).

\section{Evidence for floral preferences in stingless bees}

Stingless bees are generalist foragers of pollen and nectar (Aleixo et al., 2013, Faria et al., 2012, Absy et al., 1984). However, the tropics hold a vast range of angiosperm plant species flowering at the same time, making it a diverse and competitive marketplace for the plants. Floral rewards for pollinators differ strongly between plant species, and also vary over time (Willmer and Stone, 2004, Heinrich, 2004), encouraging some level of specialisation even among foragers that use a wide variety of plants. Each pollinator thus becomes receptive to particular flower traits in their search for food, such as flower color, morphology, scent, and temperature (Heinrich, 2004, Menzel, 1985, Dyer et al., 2006). Consistent with this, past studies done in the Neotropics have indicated that stingless bees are not indiscriminate 
generalists, but rather that they show preferences for certain families of plants such as Sapindaceae, Arecaceae, Solanaceae, Myrtaceae, Asteraceae, Melastomataceae Fabaceae and Convolvulaceae (Antonini et al., 2006, Wilms and Wiechers, 1997, Ramalho et al., 1989, da Luz et al., 2019). There is little current information on regions outside the Neotropics, nor on how these floral preferences are induced in stingless bees in their natural habitats. As they have perennial nests with overlapping generations, stingless bees may simply favour the most predictable floral resources in their particular locale. For example, in the Neotropics, the most frequently visited species belong to families that flower all year-round (Antonini et al., 2006).

Bee body size may also be a key predictor of floral preferences. Body size is related to foraging distance (Araújo et al., 2004, Greenleaf et al., 2007) and determines the spatial scale at which species are able to visit flowering plants and tolerate spatial and temporal changes in floral resource availability (Borges et al., 2020). In theory, larger bees might therefore have the scope to be choosier when it comes to floral resources, while smaller species may be more constrained to forage on the plants close to their nest. Yet the Neotropical genera Melipona and Trigona include some of the largest stingless bees, and these genera also provide some of the clearest evidence for specialisation in floral preferences (Antonini et al., 2006, Nagamitsu and Inoue, 2005, Ramalho et al., 1989). In a study in Brazil, Melipona only visited $21 \%$ out of all the plants in flower within their area of foraging. Both body size and colony size (i.e. number of foragers) might also shape floral preferences via competition. For example, species that are small in size, or have few foragers, may choose to exploit flowers less frequently visited by larger, more aggressive bees or colonies (Hubbell and Johnson, 1978, Johnson and Hubbell, 1974, Johnson and Hubbell, 1975, Sommeijer et al., 1983) which tend to monopolize rich resources (Nagamitsu et al., 1999).

\section{Visitation of non-native plants by stingless bees}

Stingless bees are reported to visit many plant genera that are not native to their region, even in areas where native vegetation is preserved (da Luz et al., 2019). Stingless bees are thus capable of facilitating the pollination and spread of non-native species (Marvier et al., 2004, Levine et al., 2004, Chytrý et al., 2008). For example, stingless bees in every region visited the genus Eucalyptus, which are trees with abundant flowering events that produce high amounts of nectar and pollen practically all year. Eucalyptus is native to Australia and cultivated in most tropical regions of the world (Doughty, 2000). Plantations of Eucalypt for timber production 
in many parts of the world cause habitat fragmentation and loss of biodiversity (Williams, 2015). However, these and other introduced plants may also provide a safe source of food for bees in degraded ecosystems (Hilgert-Moreira et al., 2014). In addition to Eucalypt, Neotropical stingless bees also forage on at least eight genera of Lamiaceae that are not native to their continent, and the stingless bees of Indo-Malayan-Australasia forage on at least 11 introduced genera of Asteraceae. Many species in these two families are considered invasive weeds. For instance, Sonchus oleraceus (Asteraceae) and Leonorus sibiricus (Lamiaceae) are catalogued as some of the worst to control weeds due to their quick life cycles and production of highly dispersive seeds (Peerzada et al., 2019, Kwon et al., 2016, Holm et al., 1977). Yet it is this same willingness to use novel resources that makes stingless bees good pollinators of some crops. Thus, stingless bees also visit and pollinate a diverse range of economically important plants that are not native to their continent. Across all regions, they visited economically important crops with mass-blooming phenology such as Coffea (coffee), Psidium (guava), Mangifera (mango), Spondias (hog-plum), Tamarindus (tamarind), among others.

\section{Gaps in our knowledge of stingless bee-plant interactions}

Our database includes reported floral visitation by 53\% of all stingless bee species (287 species). Thus, the foraging habits of the remaining half of the world's stingless bee fauna remain particularly poorly known. Even the Neotropical stingless bee fauna, for which floral use has been most intensively documented, includes many species for which data is limited. For example, while decades of research in Brazil have pioneered knowledge of stingless bee behaviour and ecology (Giannini et al., 2020), many of Brazil's rich stingless bee diversity remain little-studied (Campbell et al., 2019).

Data on stingless bee floral use from the Indo-Malayan-Australasian and Afrotropical regions is particularly sparse. With the exception of Australia and New Guinea, honey bees (Apis sp) are also native to these regions and are often the focus of traditional beekeeping practices. For example, the Asian hive bee Apis cerana is widely kept for honey and pollination throughout Asia and India (Oldroyd and Wongsiri, 2009), while the Western honey bee Apis mellifera is native throughout Africa. Perhaps for this reason, research interest in stingless bees as pollinators (of both crops and native plants) has lagged behind South and Central America in recent decades. It is now steadily increasing in some countries, such as India and Australia (Heard and Dollin, 2000), and knowledge of the bees of these regions is certain to advance in 
coming years. Many tropical regions in which stingless bee diversity is highest, however, face significant long-term challenges to conserving their ecosystems and pollination services, including high levels of poverty and habitat degradation (Bradshaw et al., 2009). In addition, many stingless bee species in Africa, India, Asia and Australia are cryptic in their morphology, and thus difficult to ID reliably in the field. For example, in Australia, three common species with overlapping distributions are identical in forager appearance, though each are genetically distinct and build unique nest structures (Tetragonula sp. of the "carbonaria complex"; (Heard, 2016).

Another key knowledge gap is the extent to which stingless bees contribute to the reproduction of the many plants they visit, including how habitat composition impacts the pollination of wild plants by stingless bees at the landscape level. Not all floral visitation results in pollination, and not all pollinators are equally efficient on a per visit basis (King et al., 2013). Pollination studies are time-intensive and difficult in the field, and most confirmed pollination by stingless bees is for crop species (Slaa et al., 2006). Where pollination of wild plants is considered, it is often in regions adjacent to crops. Yet the presence of mass-flowering crops can jeopardize the fitness of concurrently flowering wild plants by diverting pollinators, even where mass-flowering crops enhance overall abundances of generalist pollinators (Holzschuh et al., 2011). Whether stingless bees impact plant reproduction in other ways is also poorly understood. There is evidence that at least three species of stingless bees are seed dispersers for plants (mellitochory) which have evolved seeds that offer resin rewards to the bees (Wallace and Trueman, 1995, Garcia et al., 1992).

\section{Conclusion}

Tropical regions support many biodiversity hotspots (Myers et al., 2000), including a high diversity and endemism of both stingless bees and flowering plants (Hawkins et al., 2011, Antonelli et al., 2015). Just as stingless bees rely on plants as food sources for pollen and nectar, plants rely on stingless bees and other pollinators for reproduction. Here we consider for the first-time stingless plant-bee interactions at a broad, global scale, focusing on patterns at the level of bee genera and plant families. Ultimately, a rich understanding of stingless bee floral use will require continued study at local levels for the many and diverse ecosystems of the tropics and subtropics. Our database aims to provide an easy-reference and helpful initial 
resource for such future studies on the interactions between wild endemic, endangered or invasive plant species and their stingless bee visitors.

\section{Acknowledgements}

The Conselho Nacional de Desenvolvimento Científico e Tecnológico (CNPq, 149154/20186 to DAA)

\section{References}

A.B.E.L.H.A. 2017. Sistema de informação sobre interações abelhas-plantas no Brasil. [Online]. Available: http://abelhaseplantas.cria.org.br/ [Accessed 4 Nov 2020].

ABSY, M. L., CAMARGO, J. M., KERR, W. E. \& MIRANDA, I. P. D. A. 1984. Espécies de plantas visitadas por Meliponinae (Hymenoptera; Apoidea), para coleta de pólen na região do médio Amazonas. Volume 44, Número 2, Pags. 227-237.

AIZEN, M. A., SABATINO, M. \& TYLIANAKIS, J. M. 2012. Specialization and rarity predict nonrandom loss of interactions from mutualist networks. Science, 335, 14861489.

ALEIXO, K. P., DE FARIA, L. B., GARÓFALO, C. A., FONSECA, V. L. I. \& DA SILVA, C. I. 2013. Pollen collected and foraging activities of Frieseomelitta varia (Lepeletier)(Hymenoptera: Apidae) in an urban landscape. Sociobiology, 60, 266-276.

ALVES, D. A., MENEZES, C., IMPERATRIZ-FONSECA, V. L. \& WENSELEERS, T. 2011. First discovery of a rare polygyne colony in the stingless bee Melipona quadrifasciata (Apidae, Meliponini). Apidologie, 42, 211-213.

ANDERSON, M. J. 2001. A new method for non-parametric multivariate analysis of variance. Austral ecology, 26, 32-46.

ANTONELLI, A., ZIZKA, A., SILVESTRO, D., SCHARN, R., CASCALES-MIÑANA, B. \& BACON, C. D. 2015. An engine for global plant diversity: highest evolutionary turnover and emigration in the American tropics. Frontiers in Genetics, 6, 130.

ANTONINI, Y., COSTA, R. \& MARTINS, R. 2006. Floral preferences of a neotropical stingless bee, Melipona quadrifasciata Lepeletier (Apidae: Meliponina) in an urban forest fragment. Brazilian Journal of Biology, 66, 463-471.

ARAÚJO, E., COSTA, M., CHAUD-NETTO, J. \& FOWLER, H. G. 2004. Body size and flight distance in stingless bees (Hymenoptera: Meliponini): inference of flight range and possible ecological implications. Brazilian Journal of Biology, 64, 563-568.

BAUDIER, K. M., OSTWALD, M. M., GRÜTER, C., SEGERS, F. H., ROUBIK, D. W., PAVLIC, T. P., PRATT, S. C. \& FEWELL, J. H. 2019. Changing of the guard: mixed specialization and flexibility in nest defense (Tetragonisca angustula). Behavioral Ecology, 30, 1041-1049.

BENJAMINI, Y. \& HOCHBERG, Y. 1995. Controlling the false discovery rate: a practical and powerful approach to multiple testing. Journal of the Royal statistical society: series $B$ (Methodological), 57, 289-300.

BIESMEIJER, J. C., ROBERTS, S. P., REEMER, M., OHLEMÜLLER, R., EDWARDS, M., PEETERS, T., SCHAFFERS, A., POTTS, S. G., KLEUKERS, R. \& THOMAS, C. 2006. Parallel declines in pollinators and insect-pollinated plants in Britain and the Netherlands. Science, 313, 351-354. 
BORGES, R. C., PADOVANI, K., IMPERATRIZ-FONSECA, V. L. \& GIANNINI, T. C. 2020. a dataset of multi-functional ecological traits of Brazilian bees. Scientific Data, 7, 1-9.

BORRELL, B. J. 2005. Long Tongues and Loose Niches: Evolution of Euglossine Bees and Their Nectar Flowers 1. Biotropica: The Journal of Biology and Conservation, 37, 664669.

BRADSHAW, C. J., SODHI, N. S. \& BROOK, B. W. 2009. Tropical turmoil: a biodiversity tragedy in progress. Frontiers in Ecology and the Environment, 7, 79-87.

BRAMLEY, G. \& UTTERIDGE, T. M. 2014. The Kew tropical plant families identification handbook, Kew Publishing.

BUCHMANN, S. L. \& NABHAN, G. P. 2012. The forgotten pollinators, Island Press.

BUENO, F. G. B., GLOAG, R., LATTY, T. \& RONAI, I. 2020. Irreversible sterility of workers and high-volume egg production by queens in the stingless bee Tetragonula carbonaria. bioRxiv.

CABI. 2020. Invasive Species Compendium. Wallingford, UK: CAB International. www.cabi.org/isc. [Online]. [Accessed 3 Dec 2020].

CAMARGO, J. M. \& PEDRO, S. R. 2008. Revision of the species of Melipona of the fuliginosa group (Hymenoptera, Apoidea, Apidae, Meliponini). Revista Brasileira de Entomologia, 52, 411-427.

CAMPBEll, A. J., CARVAlHEIRO, L. G., GASTAUER, M., ALMEIDA-NETO, M. \& GIANNINI, T. C. 2019. Pollinator restoration in Brazilian ecosystems relies on a small but phylogenetically-diverse set of plant families. Scientific reports, 9.

CAPES. 2016. Catálogo de Teses e Dissertações [Online]. Available: http://catalogodeteses.capes.gov.br/catalogo-teses/ - !/ [Accessed 4 Nov 2020].

CHAMBERLAIN, S. A. \& SZÖCS, E. 2013. taxize: taxonomic search and retrieval in R. F1000Research, 2.

CHRISTENHUSZ, M. J. \& BYNG, J. W. 2016. The number of known plants species in the world and its annual increase. Phytotaxa, 261, 201-217.

CHYTRÝ, M., MASKELL, L. C., PINO, J., PYŠEK, P., VILÀ, M., FONT, X. \& SMART, S. M. 2008. Habitat invasions by alien plants: a quantitative comparison among Mediterranean, subcontinental and oceanic regions of Europe. Journal of Applied Ecology, 45, 448-458.

CITADINI-ZANETTE, V., NEGRELLE, R. R., LEAL-FILHO, L. S., REMOR, R., ELIAS, G. A. \& SANTOS, R. 2017. Mimosa scabrella Benth.(Fabaceae) enhances the restoration in coal mining areas in the Atlantic rainforest. Cerne, 23, 103-114.

CORE TEAM 2013. R: A language and environment for statistical computing. Vienna, Austria.

CORTOPASSI-LAURINO, M. \& RAMALHO, M. 1988. Pollen harvest by Africanized Apis mellifera and Trigona spinipes in São Paulo botanical and ecological views. Apidologie, 19, 1-24.

DA LUZ, C. F. P., FIDAlGO, A. D. O., SILVA, S. A. Y., RODRIGUES, S. D. S. \& NOCELLI, R. C. F. 2019. Comparative floral preferences in nectar and pollen foraging by Scaptotrigona postica (Latreille 1807) in two different biomes in São Paulo (Brazil). Grana, 58, 200-226.

DA SILVA, C. I., RADAESKI, J. N., ARENA, M. V. N. \& BAUERMANN, S. G. 2020. Atlas of pollen and plants used by bees.

DOUGHTY, R. W. 2000. The Eucalyptus: a natural and commercial history of the gum tree, Johns Hopkins University Press.

DYER, A. G., WHITNEY, H. M., ARNOLD, S. E., GLOVER, B. J. \& CHITTKA, L. 2006. Bees associate warmth with floral colour. Nature, 442, 525-525. 
EARDLEY, C. \& URBAN, R. 2010. Catalogue of Afrotropical bees (Hymenoptera: Apoidea: Apiformes). Zootaxa, 2455, 1-548.

FARIA, L. B. D., ALEIXO, K. P., GARÓFALO, C. A., IMPERATRIZ-FONSECA, V. L. \& SILVA, C. I. D. 2012. Foraging of Scaptotrigona aff. depilis (Hymenoptera, Apidae) in an urbanized area: Seasonality in resource availability and visited plants. Psyche, 2012.

FONTAINE, C., DAJOZ, I., MERIGUET, J. \& LOREAU, M. 2005. Functional diversity of plant-pollinator interaction webs enhances the persistence of plant communities. PLoS biology, 4, e1.

GARCIA, M. V. B., DE OLIVEIRA, M. L. \& CAMPOS, L. D. O. 1992. Use of seeds of Coussapoa asperifolia magnifolia (Cecropiaceae) by stingless bees in the Central Amazonian forest (Hymenoptera: Apidae: Meliponinae). Embrapa Amazônia Ocidental-Artigo em periódico indexado (ALICE).

GENTRY, A. H. 1980. Bignoniaceae: part I (Crescentieae and Tourrettieae). Flora Neotropica, 25, $1-130$.

GENTRY, A. H. 1992. Bignoniaceae: part II (tribe Tecomeae). Flora Neotropica, 1-370.

GIANNINI, T., BOFF, S., CORDEIRO, G., CARTOLANO, E., VEIGA, A., IMPERATRIZFONSECA, V. \& SARAIVA, A. 2015. Crop pollinators in Brazil: a review of reported interactions. Apidologie, 46, 209-223.

GIANNINI, T. C., AlveS, D. A., AlveS, R., CORDEIRO, G. D., CAMPBELl, A. J., AWADE, M., BENTO, J. M. S., SARAIVA, A. M. \& IMPERATRIZ-FONSECA, V. L. 2020. Unveiling the contribution of bee pollinators to Brazilian crops with implications for bee management. Apidologie, 1-16.

GILL, R. J., BALDOCK, K. C., BROWN, M. J., CRESSWELL, J. E., DICKS, L. V., FOUNTAIN, M. T., GARRATT, M. P., GOUGH, L. A., HEARD, M. S. \& HOLLAND, J. M. 2016. Protecting an ecosystem service: approaches to understanding and mitigating threats to wild insect pollinators. Advances in Ecological Research. Elsevier.

GREENLEAF, S. S., WILLIAMS, N. M., WINFREE, R. \& KREMEN, C. 2007. Bee foraging ranges and their relationship to body size. Oecologia, 153, 589-596.

GRÜTER, C. 2020. Stingless Bees: An Overview. Stingless Bees, 1-42.

GRÜTER, C., MENEZES, C., IMPERATRIZ-FONSECA, V. L. \& RATNIEKS, F. L. 2012. A morphologically specialized soldier caste improves colony defense in a neotropical eusocial bee. Proceedings of the National Academy of Sciences, 109, 1182-1186.

GU, Z., GU, L., EILS, R., SCHLESNER, M. \& BRORS, B. 2014. circlize implements and enhances circular visualization in R. Bioinformatics, 30, 2811-2812.

GUIBU, L., RAMALHO, M., KLEINERT-GIOVANNINI, A. \& IMPERATRIZ-FONSECA, V. 1988. Exploração dos recursos florais por colônias de Melipona quadrifasciata (Apidae, Meliponinae). Revista Brasileira de Biologia, 48, 299-305.

HAMMEL, B., VOLLET-NETO, A., MENEZES, C., NASCIMENTO, F. S., ENGELS, W. \& GRÜTER, C. 2016. Soldiers in a stingless bee: work rate and task repertoire suggest they are an elite force. The American Naturalist, 187, 120-129.

HAWKINS, B. A., RODRÍGUEZ, M. Á. \& WELLER, S. G. 2011. Global angiosperm family richness revisited: linking ecology and evolution to climate. Journal of Biogeography, $38,1253-1266$.

HEARD, T. A. 1999. The role of stingless bees in crop pollination. Annual review of entomology, 44, 183-206.

HEARD, T. A. 2016. The Australian Native Bee Book: keeping stingless bee hives for pets, pollination and sugarbag honey, Sugarbag Bees. 
HEARD, T. A. \& DOLLIN, A. E. 2000. Stingless bee keeping in Australia: snapshot of an infant industry. Bee World, 81, 116-125.

HEINRICH, B. 2004. Bumblebee economics, Harvard University Press.

HEPBURN, H. R. \& RADLOFF, S. E. 2011. Honeybees of Asia, Springer Science \& Business Media.

HILGERT-MOREIRA, S. B., FERNANDES, M. Z., MARCHETT, C. A. \& BLOCHTEIN, B. 2014. Do different landscapes influence the response of native and non-native bee species in the Eucalyptus pollen foraging, in southern Brazil? Forest Ecology and Management, 313, 153-160.

HOLM, L. G., PLUCKNETT, D. L., PANCHO, J. V. \& HERBERGER, J. P. 1977. The world's worst weeds. Distribution and biology, University press of Hawaii.

HOLZSCHUH, A., DORMANN, C. F., TSCHARNTKE, T. \& STEFFAN-DEWENTER, I. 2011. Expansion of mass-flowering crops leads to transient pollinator dilution and reduced wild plant pollination. Proceedings of the Royal Society B: Biological Sciences, 278, 3444-3451.

HUBBELL, S. P. \& JOHNSON, L. K. 1978. Comparative foraging behavior of six stingless bee species exploiting a standardized resource. Ecology, 59, 1123-1136.

INOUYE, D. W. 1978. Resource partitioning in bumblebees: experimental studies of foraging behavior. Ecology, 59, 672-678.

ISH-AM, G., BARRIENTOS-PRIEGO, F., CASTAÑEDA-VILDOZOLA, A. \& GAZIT, S. 1999. Avocado (Persea americana Mill.) pollinators in its region of origin. Revista Chapingo Serie Horticultura, 5, 137-143.

J. S. MOURE \& A. DAL MOLIN. 2012. Calliopsini Robertson, 1922. In Moure, J. S., Urban, D. \& Melo, G. A. R. (Orgs). Catalogue of Bees (Hymenoptera, Apoidea) in the Neotropical Region - online version. Available at http://www.moure.cria.org.br/catalogue. [Online]. [Accessed 3 Dec 2020].

JAFFÉ, R., POPE, N., CARVALHO, A. T., MAIA, U. M., BLOCHTEIN, B., DE CARVALHO, C. A. L., CARVALHO-ZILSE, G. A., FREITAS, B. M., MENEZES, C. \& DE FÁTIMA RIBEIRO, M. 2015. Bees for development: Brazilian survey reveals how to optimize stingless beekeeping. PloS one, 10, e 0121157.

JOHNSON, L. K. \& HUBBELL, S. P. 1974. Aggression and competition among stingless bees: field studies. Ecology, 55, 120-127.

JOHNSON, L. K. \& HUBBELL, S. P. 1975. Contrasting foraging strategies and coexistence of two bee species on a single resource. Ecology, 56, 1398-1406.

KELLERMANN, V., OVERGAARD, J., HOFFMANN, A. A., FLØJGAARD, C., SVENNING, J.-C. \& LOESCHCKE, V. 2012. Upper thermal limits of Drosophila are linked to species distributions and strongly constrained phylogenetically. Proceedings of the National Academy of Sciences, 109, 16228-16233.

KENDALL, L. K., GAGIC, V., EVANS, L. J., CUTTING, B. T., SCALZO, J., HANUSCH, Y., JONES, J., ROCCHETTI, M., SONTER, C. \& KEIR, M. 2020. Self-compatible blueberry cultivars require fewer floral visits to maximize fruit production than a partially self-incompatible cultivar. Journal of Applied Ecology.

KING, C., BALLANTYNE, G. \& WILLMER, P. G. 2013. Why flower visitation is a poor proxy for pollination: measuring single-visit pollen deposition, with implications for pollination networks and conservation. Methods in Ecology and Evolution, 4, 811-818.

KLEIJN, D. \& RAEMAKERS, I. 2008. A retrospective analysis of pollen host plant use by stable and declining bumble bee species. Ecology, 89, 1811-1823.

KLEIN, A.-M., VAISSIERE, B. E., CANE, J. H., STEFFAN-DEWENTER, I., CUNNINGHAM, S. A., KREMEN, C. \& TSCHARNTKE, T. 2006. Importance of 
pollinators in changing landscapes for world crops. Proceedings of the royal society $B$ : biological sciences, 274, 303-313.

KLEINERT, A. M., RAMALHO, M., CORTOPASSI-LAURINO, M., RIBEIRO, M. F. \& IMPERATRIZ-FONSECA, V. L. 2012. Social bees (Bombini, Apini, Meliponini). Insect Bioecology and Nutrition for Integrated Pest Management, 237-271.

KWON, S.-J., CHOI, G.-S., YOON, J.-Y., SEO, J.-K. \& CHOI, H.-S. 2016. Identification of Leonurus sibiricus as a weed reservoir for three pepper-infecting viruses. The Plant Pathology Journal, 32, 65.

LEHMBERG, L., DWORSCHAK, K. \& BLÜTHGEN, N. 2008. Defensive behavior and chemical deterrence against ants in the stingless bee genus Trigona (Apidae, Meliponini). Journal of Apicultural Research, 47, 17-21.

LEVINE, J. M., ADLER, P. B. \& YELENIK, S. G. 2004. A meta-analysis of biotic resistance to exotic plant invasions. Ecology letters, 7, 975-989.

LEWIS, G. P. 2005. Legumes of the World, Royal Botanic Gardens Kew.

MARTINEZ ARBIZU, P. 2017. pairwiseAdonis: Pairwise multilevel comparison using adonis. $R$ package version $0.0,1$.

MARVIER, M., KAREIVA, P. \& NEUBERT, M. G. 2004. Habitat destruction, fragmentation, and disturbance promote invasion by habitat generalists in a multispecies metapopulation. Risk Analysis: An International Journal, 24, 869-878.

MATEUS, S. \& NOLL, F. B. 2004. Predatory behavior in a necrophagous bee Trigona hypogea (Hymenoptera; Apidae, Meliponini). Naturwissenschaften, 91, 94-96.

MENZEL, R. 1985. Learning in honey bees in an ecological and behavioral context. Fortschritte der Zoologie (Stuttgart), 31, 55-74.

MICHENER, C. D. 1979. Biogeography of the bees. Annals of the Missouri botanical Garden, 277-347.

MICHENER, C. D. 2000. The bees of the world, JHU press.

MILLIKEN, W., KLITGÅRD, B. \& BARACAT, A. EDS, . 2009. Neotropikey - Interactive key and information resources for flowering plants of the Neotropics. www.kew.org/neotropikey [Online]. [Accessed 3 Dec 2020].

MIRANDA, E., CARVALHO, A., ANDRADE-SILVA, A., SILVA, C. \& DEL LAMA, M. 2015. Natural history and biogeography of Partamona rustica, an endemic bee in dry forests of Brazil. Insectes sociaux, 62, 255-263.

MISSOURI BOTANICAL GARDEN. 2020. Tropicos.org. Missouri Botanical Garden. $<$ http://www.tropicos.org/> [Online]. [Accessed 3 Dec 2020].

MYERS, N., MITTERMEIER, R. A., MITTERMEIER, C. G., DA FONSECA, G. A. \& KENT, J. 2000. Biodiversity hotspots for conservation priorities. Nature, 403, 853-858.

NAGAMITSU, T. \& INOUE, T. 2005. Floral resource utilization by stingless bees (Apidae, Meliponini). Pollination ecology and the rain forest. Springer.

NAGAMITSU, T., MOMOSE, K., INOUE, T. \& ROUBIK, D. W. 1999. Preference in flower visits and partitioning in pollen diets of stingless bees in an Asian tropical rain forest. Population Ecology, 41, 195-202.

NATES PARRA, G. 2016. Iniciativa Colombiana de Polinizadores Capítulo Abejas.

NOGUEIRA NETO, P. 1997. Life and keeping of indigenous stingless bees, Nogueirapis.

OKSANEN, J., BLANCHET, F. G., KINDT, R., LEGENDRE, P., MINCHIN, P. R., O'HARA, R., SIMPSON, G. L., SOLYMOS, P., STEVENS, M. H. H. \& WAGNER, H. 2013. Package 'vegan'. Community ecology package, version, 2, 1-295.

OLDROYD, B. P. \& WONGSIRI, S. 2009. Asian honey bees: biology, conservation, and human interactions, Harvard University Press.

OLLERTON, J., WINFREE, R. \& TARRANT, S. 2011. How many flowering plants are pollinated by animals? Oikos, 120, 321-326. 
PEERZADA, A. M., O’DONNELL, C. \& ADKINS, S. 2019. Biology, impact, and management of common sowthistle (Sonchus oleraceus L.). Acta Physiologiae Plantarum, 41, 136.

POTTS, S. G., IMPERATRIZ-FONSECA, V., NGO, H. T., AIZEN, M. A., BIESMEIJER, J. C., BREEZE, T. D., DICKS, L. V., GARIBALDI, L. A., HILL, R. \& SETTELE, J. 2016. Safeguarding pollinators and their values to human well-being. Nature, 540, 220 229.

POWO. 2019. Plants of the World Online. Facilitated by the Royal Botanic Gardens, Kew. Published on the Internet; http://www.plantsoftheworldonline.org/ [Online]. [Accessed 3 Dec 2020].

RAMALHO, M. 1990. Foraging by stingless bees of the genus, Scaptotrigona (Apidae, Meliponinae). Journal of Apicultural Research, 29, 61-67.

RAMALHO, M., IMPERATRIZ-FONSECA, V., KLEINEKT-GIOVANNINI, A. \& CORTOPASSL-LAURINO, M. 1985. Exploitation of floral resources by Plebeia remota Holmberg (Apidae, Meliponinae). Apidologie, 16, 307-330.

RAMALHO, M., IMPERATRIZ-FONSECA, V. \& KLEINERT-GIOVANNINI, A. 1991. Ecologia nutricional de abelhas sociais. Ecologia nutricional de insetos e suas implicações no manejo de pragas, 4, 1983.

RAMALHO, M., KLEINERT-GIOVANNINI, A. \& IMPERATRIZ-FONSECA, V. 1989a. Utilization of floral resources by species of Melipona (Apidae, Meliponinae): floral preferences. Apidologie, 20, 185-195.

RAMALHO, M., KLEINERT-GIOVANNINI, A. \& IMPERATRIZ-FONSECA, V. L. 1989b. Utilization of floral resources by species of Melipona (Apidae, Meliponinae): floral preferences. Apidologie, 20, 185-195.

RAMALHO, M., KLEINERT-GIOVANNINI, A. \& IMPERATRIZ-FONSECA, V. L. 1990. Important bee plants for stingless bees (Melipona and Trigonini) and Africanized honeybees (Apis mellifera) in neotropical habitats: a review. Apidologie, 21, 469-488.

RASMUSSEN, C. 2008. Catalog of the Indo-Malayan/Australasian stingless bees (Hymenoptera: Apidae: Meliponini), Citeseer.

RASMUSSEN, C. \& CAMERON, S. A. 2007. A molecular phylogeny of the Old World stingless bees (Hymenoptera: Apidae: Meliponini) and the non-monophyly of the large genus Trigona. Systematic Entomology, 32, 26-39.

RASMUSSEN, C. \& CAMERON, S. A. 2010. Global stingless bee phylogeny supports ancient divergence, vicariance, and long distance dispersal. Biological Journal of the Linnean Society, 99, 206-232.

RODRÍGUEZ-GIRONÉS, M. A. \& SANTAMARÍA, L. 2006. Models of optimal foraging and resource partitioning: deep corollas for long tongues. Behavioral Ecology, 17, 905-910.

ROUBIK, D. 1992a. Stingless bees: a guide to Panamanian and Mesoamerican species and their nests (Hymenoptera: Apidae: Meliponinae).

ROUBIK, D., SMITH, B. \& CARLSON, R. 1987. Formic acid in caustic cephalic secretions of stingless bee, Oxytrigona (Hymenoptera: Apidae). Journal of chemical ecology, 13, 1079-1086.

ROUBIK, D. W. 1982. Seasonality in colony food storage, brood production and adult survivorship: studies of Melipona in tropical forest (Hymenoptera: Apidae). Journal of the Kansas Entomological Society, 789-800.

ROUBIK, D. W. 1983. Nest and colony characteristics of stingless bees from Panama (Hymenoptera: Apidae). Journal of the Kansas Entomological Society, 327-355.

ROUBIK, D. W. 1992b. Ecology and natural history of tropical bees, Cambridge University Press.

ROUBIK, D. W. 1995. Pollination of cultivated plants in the tropics, Food \& Agriculture Org. 
ROUBIK, D. W. 2018. 100 Species of Meliponines (Apidae: Meliponini) in a Parcel. PotPollen in Stingless Bee Melittology, 189.

SAKAGAMI, S. F., ROUBIK, D. W. \& ZUCCHI, R. 1993. Ethology of the robber stingless bee, Lestrimelitta limao (Hymenoptera: Apidae). Sociobiology.

SCHUH, R. T., S. HEWSON-SMITH, AND J.S. ASCHER., 2010. Specimen databases: A case study in entomology using web-based software. American Entomologist 56: 206-216.

SHACKLETON, K., AL TOUFAILIA, H., BALFOUR, N. J., NASCIMENTO, F. S., ALVES, D. A. \& RATNIEKS, F. L. 2015. Appetite for self-destruction: suicidal biting as a nest defense strategy in Trigona stingless bees. Behavioral ecology and sociobiology, 69, 273-281.

SIMPSON, M. G. 2010. Diversity and classification of flowering plants: eudicots. Plant Systematics (Second Edition), Academic Press, San Diego, 275-448.

SLAA, E. J., CHAVES, L. A. S., MALAGODI-BRAGA, K. S. \& HOFSTEDE, F. E. 2006. Stingless bees in applied pollination: practice and perspectives. Apidologie, 37, 293315.

SOMMEIJER, M., CHINH, T. \& MEEUWSEN, F. 1999. Behavioural data on the production of males by workers in the stingless bee Melipona favosa (Apidae, Meliponinae). Insectes Sociaux, 46, 92-93.

SOMMEIJER, M., DE ROOY, G., PUNT, W. \& DE BRUIJN, L. 1983. A comparative study of foraging behavior and pollen resources of various stingless bees (Hym., Meliponinae) and honeybees (Hym., Apinae) in Trinidad, West-Indies. Apidologie, 14, 205-224.

THE PLANT LIST. 2010. Version 1. Published on the Internet; http://www.theplantlist.org/ [Online]. [Accessed 3 Dec 2020].

TORRES, C. \& GALETTO, L. 2002. Are nectar sugar composition and corolla tube length related to the diversity of insects that visit Asteraceae flowers? Plant biology, 4, 360366.

VALDEZ-HERNÁNDEZ, M., SÁNCHEZ, O., ISLEBE, G. A., SNOOK, L. K. \& NEGREROS-CASTILLO, P. 2014. Recovery and early succession after experimental disturbance in a seasonally dry tropical forest in Mexico. Forest Ecology and Management, 334, 331-343.

VANBERGEN, A. J. \& INITIATIVE, T. I. P. 2013. Threats to an ecosystem service: pressures on pollinators. Frontiers in Ecology and the Environment, 11, 251-259.

VELTHUIS, H. H., DE VRIES, H. \& IMPERATRIZ-FONSECA, V. L. 2006. The polygyny of Melipona bicolor: scramble competition among queens.

VIT, P., PEDRO, S. R. \& ROUBIK, D. W. 2018. Pot-pollen in stingless bee melittology, Springer.

VOSSLER, F. G. 2013. Estudio palinológico de las reservas alimentarias (miel y masas de polen) de abejas nativas sin aguijón (Hymenoptera, Apidae, Meliponini): un aporte al conocimiento de la interacción abeja-planta en el Chaco seco de Argentina. Universidad Nacional de La Plata.

WALLACE, H. M. \& TRUEMAN, S. J. 1995. Dispersal of Eucalyptus torelliana seeds by the resin-collecting stingless bee, Trigona carbonaria. Oecologia, 104, 12-16.

WILLE, A. 1983. Biology of the stingless bees. Annual review of entomology, 28, 41-64.

WILLIAMS, R. A. 2015. Mitigating biodiversity concerns in Eucalyptus plantations located in South China. Journal of Biosciences and Medicines, $3,1$.

WILLMER, P. \& STONE, G. 2004. Behavioral, ecological, and physiological determinants of the activity patterns of bees. Advances in the Study of Behavior, 34, 347-466. 
bioRxiv preprint doi: https://doi.org/10.1101/2021.04.26.440550; this version posted April 27, 2021. The copyright holder for this preprint

(which was not certified by peer review) is the author/funder, who has granted bioRxiv a license to display the preprint in perpetuity. It is made available under aCC-BY-ND 4.0 International license.

WILMS, W. \& WIECHERS, B. 1997. Floral resource partitioning between native Melipona bees and the introduced Africanized honey bee in the Brazilian Atlantic rain forest. Apidologie, 28, 339-355. 